\title{
A comparison of the effects of kaempferol and quercetin on cytokine-induced pro-inflammatory status of cultured human endothelial cells
}

\author{
Irene Crespo, María V. García-Mediavilla, Belén Gutiérrez, Sonia Sánchez-Campos, María J. Tuñón \\ and Javier González-Gallego* \\ Centro de Investigación Biomédica en Red de Enfermedades Hepáticas y Digestivas (CIBEREHD) and Institute of Biomedicine, \\ University of León, León 24071, Spain
}

(Received 9 October 2007 - Revised 31 January 2008 - Accepted 4 February 2008 - First published online 8 April 2008)

\begin{abstract}
We investigated the effects of the flavonols kaempferol and quercetin on the expression of vascular cell adhesion molecule-1 (VCAM-1), intercellular adhesion molecule-1 (ICAM-1), endothelial cell selectin (E-selectin), inducible NO synthase (iNOS) and cyclo-oxygenase-2 (COX-2), and on the activation of the signalling molecules NF- $\mathrm{\kappa B}$ and activator protein-1 (AP-1), induced by a cytokine mixture in cultured human umbilical vein endothelial cells. Inhibition of reactive oxygen and nitrogen species generation did not differ among both flavonols at $1 \mu \mathrm{mol} / \mathrm{l}$ but was significantly stronger for kaempferol at 5-50 $\mu \mathrm{mol} / \mathrm{l}$. Supplementation with increasing concentrations of kaempferol substantially attenuated the increase induced by the cytokine mixture in VCAM-1 $(10-50 \mu \mathrm{mol} / \mathrm{l})$, ICAM-1 $(50 \mu \mathrm{mol} / \mathrm{l})$ and E-selectin $(5-50 \mu \mathrm{mol} / \mathrm{l})$ expression. A sig-

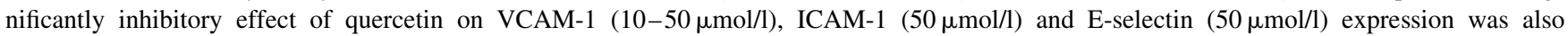
observed. Expression of adhesion molecules was always more strongly inhibited in kaempferol-treated than in quercetin-treated cells. The inhibitory effect on iNOS and COX-2 protein level was stronger for quercetin at 5-50 $\mu \mathrm{mol} / \mathrm{l}$. The effect of kaempferol on NF- $\mathrm{KB}$ and AP-1 binding activity was weaker at high concentrations $(50 \mu \mathrm{mol} / \mathrm{l})$ as compared with quercetin. The present study indicates that differences exist in the modulation of pro-inflammatory genes and in the blockade of NF-кB and AP-1 by kaempferol and quercetin. The minor structural differences between both flavonols determine differences in their anti-inflammatory properties and in their efficiency in inhibiting signalling molecules.
\end{abstract}

Flavonoids: Endothelial cells: Adhesion molecules: Inflammation

Vascular endothelial cells line the luminal side of blood vessels and mediate the interactions between blood vessels and between blood and tissue, thus playing a key role in a number of important physiological and pathological processes $^{(1)}$. Activation of the vascular endothelium, increased adhesion of mononuclear cells to the injured endothelium and subsequent transmigration into the tissue are central to the development of atherosclerosis ${ }^{(2)}$. Endothelial cells characteristically respond to pro-inflammatory stimuli such as $\mathrm{TNF}-\alpha$, bacterial lipopolysaccharide and IL- $1 \beta$, and recruit leucocytes by selectively expressing adhesion molecules on the surface such as vascular cell adhesion molecule-1 (VCAM-1), intercellular adhesion molecule-1 (ICAM-1) and endothelial cell selectin (E-selectin) ${ }^{(3,4)}$. These cell adhesion molecules play an important role in the early stages of atherosclerosis, and even participate in the inflammatory reaction in more advanced atherosclerotic lesions ${ }^{(5)}$.

The production of NO is necessary for the physiological function of the endothelium by inhibiting monocyte adhesion and smooth muscle cell chemotaxis, and proliferation ${ }^{(6)}$. However, high levels of NO sufficient to induce inflammatory effects may be produced by inducible NO synthase (iNOS) in response to cytokine stimulation, thus contributing to the progression of atherosclerosis ${ }^{(5)}$. In fact, the use of selective iNOS inhibitors succesfully retards development of atherosclerosis induced by a high-cholesterol $\operatorname{diet}^{(7)}$. Moreover, reaction of NO with superoxide may generate the highly cytotoxic molecule peroxynitrite ${ }^{(8)}$. Cyclo-oxygenase-2 (COX-2) has also been associated with pro-inflammatory and pro-atherogenic stages due to the generation of lipid mediators of inflammation $^{(9)}$, although its role as a determinant of plaque vulnerability depends on the PG synthesis coupled with it and some COX-2 inhibitors increase the risk of cardiovascular events $^{(10)}$.

There is currently intense interest in polyphenolic phytochemicals such as flavonoids, proanthocyanidins and phenolic acids $^{(11)}$. Epidemiological studies have shown that a high consumption of these polyphenolics is inversely related to the risk

Abbreviations: AP-1, activator protein-1; COX-2, cyclo-oxygenase-2; DCFH-DA, $2^{\prime}, 7^{\prime}$-dichlorofluorescein diacetate; E-selectin, endothelial cell selectin; HUVEC, human umbilical vein endothelial cells; ICAM-1, intercellular adhesion molecule-1; iNOS, inducible NO synthase; MTT, 3-(4,5-dimethylthiazol-2-yl)-2,5diphenyltetrazolium bromide; RNS, reactive nitrogen species; ROS, reactive oxygen species; Tris, 2-amino-2-(hydroxymethyl)propane-1,3-diol; VCAM-1, vascular cell adhesion molecule-1.

* Corresponding author: Dr J. González-Gallego, fax +34 987 291267, email jgonga@ unileon.es 
of $\mathrm{CVD}^{(12,13)}$ and it is known that they affect the development of atherosclerosis not only through modulation of serum lipids but also by influencing the inflammatory processes associated with this disease ${ }^{(14)}$. Flavonoids inhibit endothelial induction of cell adhesion molecules in TNF- $\alpha$-activated human endothelial cells ${ }^{(15)}$ and protect against endothelial cell damage induced by oxidants by down-regulating iNOS and COX-2 expression $^{(16)}$.

Flavonoids differing in the type and numbers of substitution patterns show different anti-inflammatory and free radicalscavenging activities ${ }^{(17)}$, and although the antioxidant potency of flavonoids in cell-free studies has been reported to depend on structural characteristics such as the arrangement of hydroxyl groups on the benzene ring ${ }^{(18)}$, structure dependency in live cells is less clear. Flavonols are the strongest antioxidants among flavonoids ${ }^{(19)}$. Quercetin $\left(3,3^{\prime}, 4^{\prime}, 5,7\right.$-pentahydroxyflavone) and kaempferol (3,4',5,7-tetrahydroxyflavone) are flavonols which exhibit minor different structural characteristics. Quercetin, with two $-\mathrm{OH}$ moieties on the B-ring, is found in many fruits and vegetables, as well as in red wine, olive oil and tea. Kaempferol, with one $-\mathrm{OH}$ moiety on the B-ring, is present in broccoli, Ginkgo biloba, fruits and vegetables ${ }^{(20)}$. The anti-inflammatory activities of quercetin and kaempferol have been partially described in the literature, with differences that might be due to effects being tissue and concentration dependent ${ }^{8,21)}$. For this reason we decided to analyse the efficacy of both flavonoids as anti-inflammatory compounds in cultured human endothelial cells, by evaluating in a concentration-dependent manner their effects in terms of the ability to modulate adhesion molecules, iNOS and COX-2 expression. Flavonoids delivered through human diets are at low doses, in most cases they do not escape first-pass metabolism $^{(22)}$, and the predominant forms present in plasma are conjugates $^{(23)}$. However, inflammatory processes activate glucuronidases that can break down the flavonoid metabolites in the parent aglycone ${ }^{(24-25)}$, and in recent years novel targeting approaches are being tested to improve the therapeutic potential $^{(26)}$ and the delivery of flavonoids to tissues of interest $^{(27,28)}$. Therefore, in the present study, a range of physiological and non-toxic supraphysiological concentrations of the parent quercetin and kaempferol aglycones were tested.

Inflammatory genes, such as those encoding for adhesion molecules, iNOS and COX-2, are regulated by a variety of transcription factors ${ }^{(29)}$. It appears that $\mathrm{NF}-\kappa \mathrm{B}$ and activator protein-1 (AP-1) play critical roles in these regulatory processes. Binding sites for NF- $\kappa$ B and AP-1 have been identified in the promoter regions of various inflammatory genes ${ }^{(30,31)}$, and nuclear traslocation of both transcription factors has been reported in atherosclerotic vessels ${ }^{(32,33)}$. Therefore, in the present study we also investigated if differences in the anti-inflammatory properties of kaempferol and quercetin were related to their interference with the activation of NF- $\kappa \mathrm{B}$ and AP-1.

\section{Methods}

Cells, cell culture and cytokine activation protocol

Human umbilical vein endothelial cells (HUVEC; ATCC 1730CRL; American Type Culture Collection, Manassas, VA, USA) were maintained in F12K Nutrient Mixture (Kaighn's modification) medium (Gibco BRL, Grand Island, NY, USA) supplemented with $10 \%(\mathrm{v} / \mathrm{v})$ fetal bovine serum, endothelial cell growth supplement $(30 \mu \mathrm{g} / \mathrm{ml}$; Sigma, St Louis, MO, USA), heparin $(10 \mathrm{U} / \mathrm{ml}$; Sigma), penicillin $(100 \mathrm{U} / \mathrm{ml})$ and streptomycin $(100 \mu \mathrm{g} / \mathrm{ml}$; Gibco BRL). Cells were maintained at $37^{\circ} \mathrm{C}$ and $5 \% \mathrm{CO}_{2}$ in gelatin-coated $75 \mathrm{~cm}^{2}$ culture flasks.

After $48 \mathrm{~h}$, the medium was changed to include a cytokine mixture containing human recombinant IL- $1 \beta$, TNF- $\alpha$ and interferon- $\gamma(250 \mathrm{IU} / \mathrm{ml}$ each) (Genzyme Corp., Boston, MA, USA), as previously described ${ }^{(34)}$ with or without kaempferol or quercetin $(1,5,10$ or $50 \mu \mathrm{mol} / \mathrm{l})$ dissolved in dimethyl sulfoxide $(0.05 \%, \mathrm{v} / \mathrm{v})$. Thus the cells were incubated an additional $24 \mathrm{~h}$, a time period previously considered in a similar study ${ }^{(35)}$. After treatment, cells were trypsinised, pelleted and washed with cold PBS and stored at $-70^{\circ} \mathrm{C}$ until assayed.

\section{Cell viability in cell culture using 3-(4,5-dimethylthiazol-2-yl)-} 2,5-diphenyltetrazolium bromide

The cell viability was assessed by the mitochondrial function, measured by 3-(4,5-dimethylthiazol-2-yl)-2,5-diphenyltetrazolium bromide (MTT) reduction activity as previously reported ${ }^{(36)}$. Briefly, cells were seeded in a twenty-four-well plate and incubated with the cytokine mixture with or without kaempferol or quercetin $(1,5,10$ or $50 \mu \mathrm{mol} / \mathrm{l})$. After $24 \mathrm{~h}$, the cells were incubated with MTT $(0.5 \mathrm{mg} / \mathrm{ml}$; Sigma $)$ for $2 \mathrm{~h}$ at $37^{\circ} \mathrm{C}$. Subsequently, the media were aspirated and the cells were lysed with dimethyl sulfoxide, whereafter the absorbance was read at $560 \mathrm{~nm}$, with background substraction at $650 \mathrm{~nm}$, using a microplate reader (Bio-Rad Laboratories, Veenendaal, The Netherlands).

\section{Generation of reactive oxygen and nitrogen species by flow cytometry}

The reactive oxygen species (ROS) and reactive nitrogen species (RNS) production was assessed by flow cytometry as the fluorescence of $2^{\prime}, 7^{\prime}$-dichlorofluorescein, which is the oxidation product of $2^{\prime}, 7^{\prime}$-dichlorofluorescein diacetate (DCFH-DA; Sigma), with a sensitivity for $\mathrm{H}_{2} \mathrm{O}_{2} / \mathrm{NO}$-based radicals ${ }^{(34)}$. At the end of the incubation period cells were incubated with $5 \mu \mathrm{M}$-DCFH-DA for $45 \mathrm{~min}$ at $37^{\circ} \mathrm{C}$ then washed twice, re-suspended in PBS, and analysed on a FACS Calibur flow cytometer (Becton Dickinson Biosciences, San Jose, CA, USA).

Western blot for vascular cell adhesion molecule-1, intercellular adhesion molecule-1, endothelial cell selectin, inducible nitric oxide synthase and cyclo-oxygenase-2

At the end of the incubation period, protein extraction and Western blotting were performed as described ${ }^{(37)}$. Cell lysates were prepared in $0.25 \mathrm{~mm}$-sucrose, $1 \mathrm{~mm}$-EDTA, $10 \mathrm{mM}-2$ amino-2-(hydroxymethyl)propane-1,3-diol (Tris) and $1 \%$ $(\mathrm{w} / \mathrm{v})$ protease inhibitor cocktail. The mixture was incubated for $30 \mathrm{~min}$ at $4^{\circ} \mathrm{C}$ and centrifuged for $30 \mathrm{~min}$ at $13000 \mathrm{~g}$ at $4^{\circ} \mathrm{C}$. The supernatant fraction was kept as HUVEC extracts. Samples containing $75 \mu \mathrm{g}$ protein were separated by SDSPAGE ( $9 \%$ acrylamide) and transferred to nitrocellulose. Non-specific binding was blocked by preincubation of the nitrocellulose in PBS containing $5 \%$ bovine serum 
albumin for $1 \mathrm{~h}$. The nitrocellulose was then incubated overnight at $4{ }^{\circ} \mathrm{C}$ with rabbit polyclonal anti-iNOS (Biomol International, Plymouth Meeting, PA, USA), rabbit polyclonal anti-COX-2 (Abcam, Cambridge, UK), rabbit polyclonal anti-VCAM-1, rabbit polyclonal anti-ICAM-1, or rabbit polyclonal anti-E-selectin (Santa Cruz Biotechnology, Inc., Santa Cruz, CA, USA). Bound primary antibody was detected with horseradish peroxidase-conjugated anti-rabbit antibody (DAKO, Glostrup, Denmark) and blots were developed using an enhanced chemiluminescence detection system (ECL kit; Amersham Pharmacia, Uppsala, Sweden). Equal loading of the gels was demonstrated by probing the membranes with an anti- $\beta$-actin polyclonal antibody. The density of the specific bands was quantified with an imaging densitometer (Scion Image, Frederick, MD, USA).

\section{Electrophoretic mobility shift assay for nuclear factor- $\kappa B$} and activator protein-1

After $12 \mathrm{~h}$ of incubation with cytokine mixture with or without kaempferol or quercetin at different concentrations, nuclear extracts were prepared as previously described ${ }^{(38)}$. Activation of transcription factor $N F-\kappa B$ was examined in nuclear extracts using consensus oligonucleotides of NF- $\mathrm{kB}$ (5'-AGT TGA GGG GAC TTT CCC AGG C-3' $)^{(39)}$ or for the AP-1 consensus site (5'-CGC TTG ATG ACT CAG CCG GAA-3'). Probes were labelled by $\mathrm{T} 4$ polynucleotide kinase. Binding reactions included $10 \mu \mathrm{g}$ of nuclear extracts in incubation buffer (50 mM-Tris-HCl (pH 7.5), $200 \mathrm{~mm}-$ $\mathrm{NaCl}, 5 \mathrm{~mm}$-EDTA, $5 \mathrm{~mm}$-mercaptoethanol, $20 \%$ (v/v) glycerol and $1 \mu \mathrm{g}$ poly $(\mathrm{dI}-\mathrm{dC}))$. After $15 \mathrm{~min}$ on ice, the labelled oligonucleotide (30000 counts per min) was added and the mixture incubated for $20 \mathrm{~min}$ at room temperature. For competition studies, $3.5 \mathrm{pmol}$ of unlabelled NF- $\mathrm{KB}$ or AP-1 oligonucleotides (competitor) or $3.5 \mathrm{pmol}$ of labelled NF- $\kappa$ B or AP-1 oligonucleotide mutate (non-competitor) were mixed $15 \mathrm{~min}$ before the incubation with the labelled oligonucleotide. The mixture was electrophoresed through a $6 \%(\mathrm{w} / \mathrm{v})$ polyacrylamide gel for $90 \mathrm{~min}$ at $220 \mathrm{~V}$. The gel was then dried and autoradiographed at $-70^{\circ} \mathrm{C}$ overnight. Signals were densitometrically analysed in an imaging densitometer (Scion Image).

\section{Statistical analysis}

Mean values with their standard errors were calculated. Data were analysed using ANOVA. Post hoc comparisons were carried out by the Newman-Keuls test. Statistical significance was set at $P<0 \cdot 05$. SPSS+ (version 13.0 statistical software; SPSS, Inc., Chicago, IL, USA) was used.

\section{Results}

\section{Cell viability}

Cell viability was assessed by the MTT test. Incubation for $24 \mathrm{~h}$ with the cytokine mixture and $1,5,10$ and $50 \mu \mathrm{M}$-kaempferol or -quercetin did not significantly decrease cell viability $(P>0.05$; data not shown). Accordingly, these four concentrations of both flavonols were used for culture experiments.
Effects of flavonols on reactive oxygen and reactive nitrogen species generation

We investigated generation of ROS and RNS by flow cytometry using DCFH-DA. Analysis of histograms in which the fluorescence, detected with the green fluorescence (FL1-H) channel, was plotted against the relative number of events (Fig. 1 (a) and (b)) and quantification of the corresponding fluorescence intensity (Fig. 1 (c)) indicated that the cytokine mixture induced a significant increase in ROS and RNS production as compared with unstressed controls. Treatment of cells with kaempferol or quercetin at $5-50 \mu \mathrm{mol} / \mathrm{l}$ significantly decreased ROS and RNS production in a concentration-dependent manner. Inhibition of ROS and RNS generation was significantly stronger for kaempferol when compared with quercetin at those concentrations.

Effects of flavonols on adhesion molecules, inducible nitric oxide synthase and cyclo-oxygenase-2 protein levels

Data presented in Fig. 2 show the effects of kaempferol and quercetin on VCAM-1, ICAM-1 and E-selectin protein levels. The three adhesion molecules were markedly expressed in cytokine-stimulated cells. Supplementation with increasing concentrations of kaempferol substantially attenuated the increase induced by the cytokine mixture in VCAM-1 $(10-50 \mu \mathrm{mol} / \mathrm{l}), \quad$ ICAM-1 $(50 \mu \mathrm{mol} / \mathrm{l})$ and E-selectin $(5-50 \mu \mathrm{mol} / \mathrm{l})$ expression. A significantly inhibitory effect of quercetin on VCAM-1 (10-50 $\mu \mathrm{mol} / \mathrm{l})$, ICAM-1 $(50 \mu \mathrm{mol} / \mathrm{l})$ and E-selectin $(50 \mu \mathrm{mol} / \mathrm{l})$ expression was also observed. Expression of adhesion molecules was always more strongly inhibited in kaempferol-treated than in quercetin-treated cells.

Stimulation of HUVEC with the cytokine mixture also caused a marked increase in iNOS and COX-2 protein level (Fig. 3). Kaempferol at $5-50 \mu \mathrm{mol} / \mathrm{l}$ and quercetin at $1-50 \mu \mathrm{mol} / \mathrm{l}$ evoked a concentration-dependent inhibition on iNOS expression. Both flavonols inhibited COX-2 expression in a concentration-dependent manner at $5-50 \mu \mathrm{mol} / 1$. The attenuation of iNOS and COX-2 protein level expression was significantly stronger for quercetin than for kaempferol at $5-10 \mu \mathrm{mol} / \mathrm{l}$.

\section{Effects of flavonols on nuclear factor- $\kappa B$ and activator protein-1 activations}

Electrophoretic mobility shift assays were conducted to investigate DNA-binding activities of the transcription factors NF- $\mathrm{BB}$ and AP-1 in nuclear extracts of HUVEC. The specificity of each DNA binding was assessed by competition of non-labelled oligonucleotide. As shown in Figs. 4 and 5, cytokine-stimulated HUVEC showed increased NF$\kappa \mathrm{B}$ and AP-1 DNA-binding activities. Treatment with kaempferol at $1-50 \mu \mathrm{mol} / \mathrm{l}$ significantly attenuated this effect. The inhibitory action of quercetin was significant at $5-50 \mu \mathrm{mol} / 1$ on NF- $\kappa \mathrm{B}$ and at $50 \mu \mathrm{mol} / 1$ on $\mathrm{AP}-1$. Inhibition of NF- $\mathrm{BB}$ and AP-1 binding activity was significantly weaker in kaempferol-treated than in quercetin-treated cells at $50 \mu \mathrm{mol} / \mathrm{l}$. 
(a)

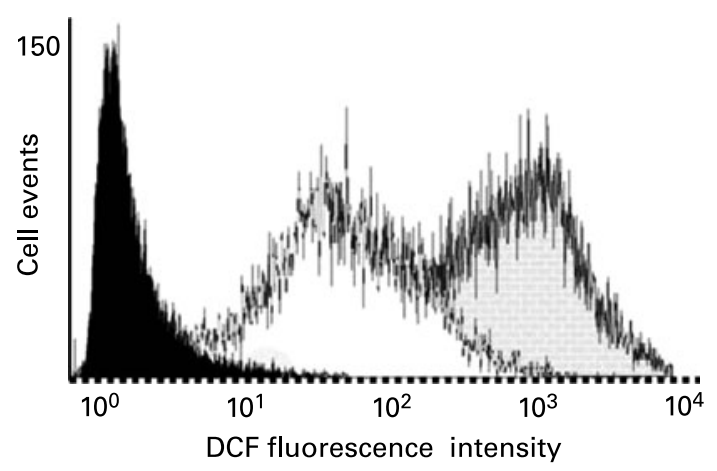

(b)

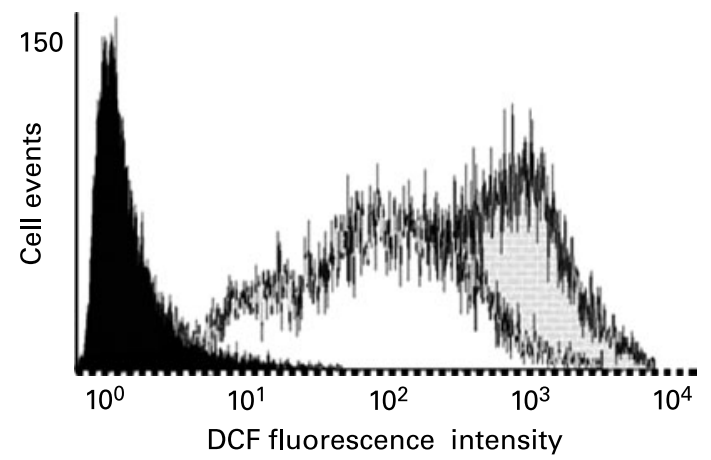

(c)

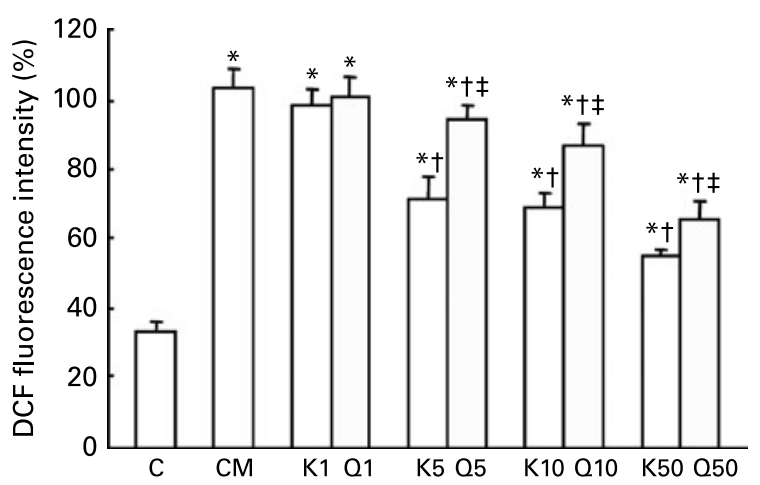

Fig. 1. Effect of flavonoids on intracellular reactive oxygen and nitrogen species generation in human umbilical vein endothelial cells measured by flow cytometry with $2^{\prime}, 7^{\prime}$-dichlorofluorescein diacetate. Cells were incubated for $24 \mathrm{~h}$ with a cytokine mixture (CM) and 1 to $50 \mu \mathrm{M}$-kaempferol (K) or -quercetin (Q). (a) Representative histogram of $2^{\prime}, 7^{\prime}$-dichlorofluorescein (DCF) fluorescence in CM cells (回) and kaempferol-treated cells $(50 \mu \mathrm{M}$; $\square$ ) compared with control cells (घ). The fluorescence (FL1, green fluorescence) is plotted against the number of events. (b) Representative histogram of DCF fluorescence in CM cells (國) and quercetin-treated cells $(50 \mu \mathrm{M}$; $\square$ ) compared with control cells $(\mathbf{\square})$. The FL1-H is plotted against the number of events. (c) Fluorescence intensity as percentage of control (C) values. Data are means from four separate experiments, with standard errors represented by vertical bars. ${ }^{*}$ Mean value was significantly different from that of the control group $(P<0.05)$. $†$ Mean value was significantly different from that of the $\mathrm{CM}$-treated group $(P<0.05)$. $¥$ Mean value was significantly different from that of the kaempferol-treated group at the same concentration $(P<0.05)$.

\section{Discussion}

In general, free radical scavenging by flavonoids occurs via electron donation from the free hydroxyls on the flavonoid nucleus with the formation of less reactive aroxyl radicals ${ }^{(40)}$. For this reason, it has been suggested that flavonols, which have three $-\mathrm{OH}$, are the strongest antioxidants among flavonoids $^{(41)}$. The B-ring $\mathrm{OH}$ moiety has been shown to be the

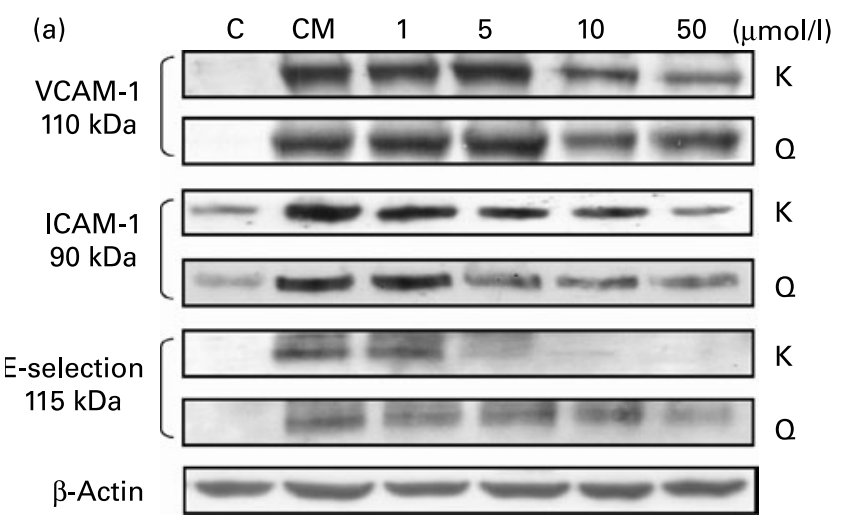

(b)

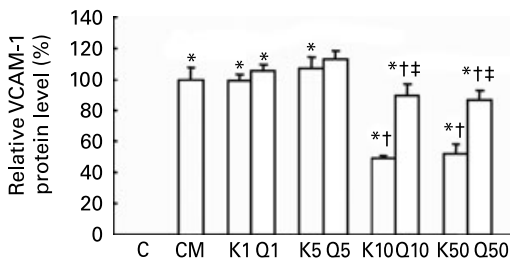

(c)

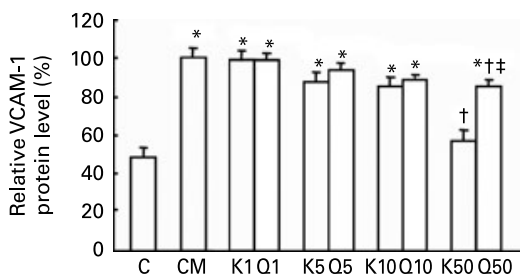

(d)

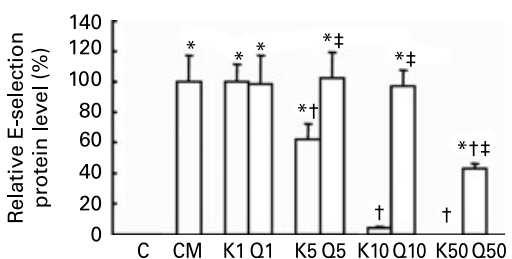

Fig. 2. Effect of flavonoids on vascular cell adhesion molecule-1 (VCAM-1), intercellular adhesion molecule-1 (ICAM-1) and E-selectin protein concentrations in human umbilical vein endothelial cells. Cells were incubated for $24 \mathrm{~h}$ with a cytokine mixture $(\mathrm{CM})$ and 1 to $50 \mu \mathrm{M}$-kaempferol $(\mathrm{K})$ or -quercetin (Q). Total cellular protein was separated on $9 \%$ SDS-polyacrylamide gels and blotted with anti-VCAM-1, anti-ICAM-1 and anti-E-selectin antibodies. (a) Representative Western blots. C, control. (b) Densitometric anaIysis of Western blot for VCAM-1. (c) Densitometric analysis of Western blot for ICAM-1. (d) Densitometric analysis of Western blot for E-selectin. Data are means from four separate experiments, normalised to levels of $\beta$-actin, with standard errors represented by vertical bars. * Mean value was significantly different from that of the control group $(P<0.05)$. † Mean value was significantly different from that of the CM-treated group $(P<0.05)$. $\ddagger$ Mean value was significantly different from that of the kaempferol-treated group at the same concentration $(P<0.05)$. 
most significant determinant factor in scavenging the ROS and $\mathrm{RNS}^{(42)}$. The study antioxidant capacity of flavonols in cell-free systems supports this concept, showing that the one $-\mathrm{OH}$ moiety difference between quercetin and kaempferol supposes a higher antioxidant activity in the former ${ }^{(35)}$. However, the intracellular antioxidant activity of flavonoids is not always parallel to that in cell-culture media ${ }^{(35)}$. In fact, in the present study, generation of ROS and RNS induced by a cytokine mixture in cultured HUVEC was attenuated to a higher degree by kaempferol. Therefore, it appears that the antioxidant effect is not simply related to the number of $-\mathrm{OH}$ moieties of the B-ring. Some other structural features might be governing this effect. Thus, with one less $-\mathrm{OH}$ group, the lipophilicity of kaempferol is increased when compared with quercetin, probably as a result of a decrease in the formation of hydrogen bonds with water molecules ${ }^{(43)}$. An increased antioxidant efficiency is in the inverse order to the ability of flavonoids to establish hydrogen bonds ${ }^{(44)}$. The higher antioxidant activity of the kaempferol can also result from its non-planar structure, which confers a higher flexibility to conformational changes ${ }^{(45)}$, and a higher permeation

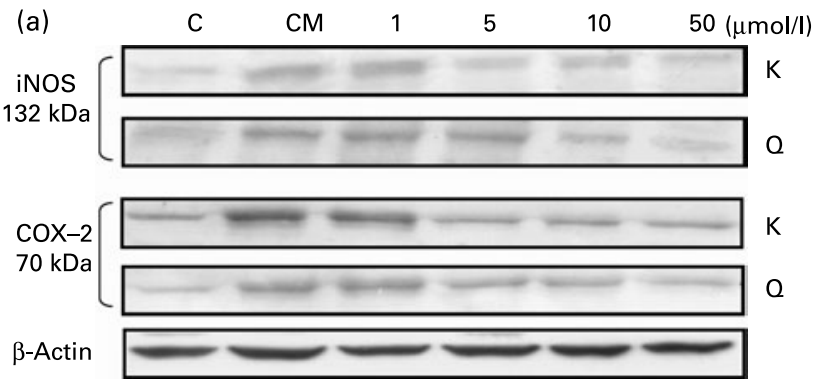

(b)

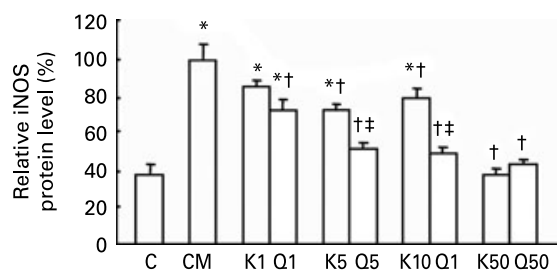

(c)

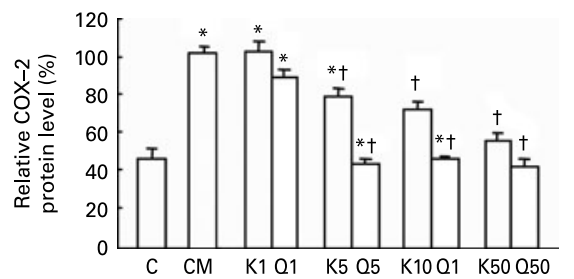

Fig. 3. Effect of flavonoids on inducible NO synthase (iNOS) and cyclo-oxygenase-2 (COX-2) protein concentrations in human umbilical vein endothelial cells. Cells were incubated for $24 \mathrm{~h}$ with a cytokine mixture (CM) and 1 to $50 \mu \mathrm{M}$-kaempferol $(\mathrm{K})$ or -quercetin $(\mathrm{Q})$. Total cellular protein was separated on $9 \%$ SDS-polyacrylamide gels and blotted with anti-iNOS and anti-COX-2 antibodies. (a) Representative Western blots. C, control. (b) Densitometric analysis of Western blot for iNOS. (c) Densitometric analysis of Western blot for COX-2. Data are means from four separate experiments, normalised to levels of $\beta$-actin, with standard errors represented by vertical bars. ${ }^{*}$ Mean value was significantly different from that of the control group $(P<0.05)$. † Mean value was significantly different from that of the CM-treated group $(P<0.05)$. ¥Mean value was significantly different from that of the kaempferol-treated group at the same concentration $(P<0.05)$. through the plasma membrane, as compared with the more rigid structure of quercetin. Quercetin, catechins and probably most polyphenolic compounds interact with commonly used cell-culture media to generate high levels of $\mathrm{H}_{2} \mathrm{O}_{2}{ }^{(46)}$, and it has been reported that the activity decreasing intracellular ROS is inversely related to the $\mathrm{H}_{2} \mathrm{O}_{2}$-scavenging activity of flavonoids. These results suggest that strong antioxidative flavonoids have both a cytoprotective effect owing to the scavenging of ROS and a cytotoxic effect caused by the generation of $\mathrm{H}_{2} \mathrm{O}_{2}$, and differences in the last could exist among quercetin and kaempferol ${ }^{(47)}$.

Gerritsen et al. ${ }^{(48)}$ were the first to demonstrate that hydroxyl flavones and flavonols are the most effectual flavonoids in inhibiting cytokine-induced expression of ICAM-1, VCAM-1 and E-selectin in HUVEC. Protective effects on endothelial cells have been later confirmed by other authors, although differences in the inhibitory potency of flavonoids have been reported. Thus, while Gerritsen et al. ${ }^{(48)}$ observed significant inhibition of VCAM-1 expression by flavonoid concentrations lower than $30 \mu \mathrm{mol} / \mathrm{l}$ and Tribolo et al. ${ }^{(23)}$ found inhibition by quercetin of VCAM-1 at $10 \mu \mathrm{mol} / \mathrm{l}$ and ICAM-1 at $2-10 \mu \mathrm{mol} / \mathrm{l}$, both Choi et al. ${ }^{(15)}$ and Lotito \& Frei $^{(49)}$ reported inhibition of adhesion molecule proteins by quercetin only at concentrations greater than $25 \mu \mathrm{mol} / \mathrm{l}$. Our data demonstrated a significant inhibition of both ICAM-1 and E-selectin expression at $50 \mu \mathrm{mol} / \mathrm{l}$ by quercetin, which

(a)
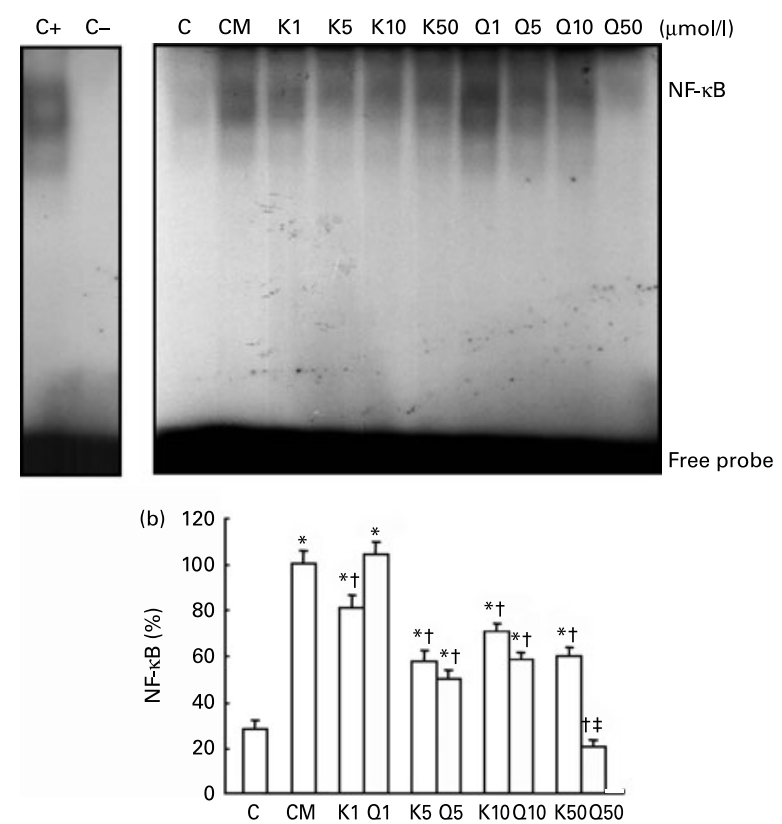

Fig. 4. Effect of flavonoids on NF-кB activation in human umbilical vein endothelial cells. Cells were incubated for $12 \mathrm{~h}$ with a cytokine mixture $(\mathrm{CM})$ and 1 to $50 \mu \mathrm{M}$-kaempferol (K) or -quercetin (Q). (a) A representative electrophoretic mobility shift assay (EMSA). Specific binding was verified by the addition of unlabelled (cold) oligonucleotide (competitor, C- ) or labelled oligonucleotide mutate (non-competitor, $\mathrm{C}+$ ). (b) Densitometric analysis of EMSA. Data are means from four separate experiments, with standard errors represented by vertical bars. * Mean value was significantly different from that of the control group $(P<0.05)$. † Mean value was significantly different from that of the CM-treated group $(P<0 \cdot 05)$. $¥$ Mean value was significantly different from that of the kaempferol-treated group at the same concentration $(P<0.05)$. 
(a)

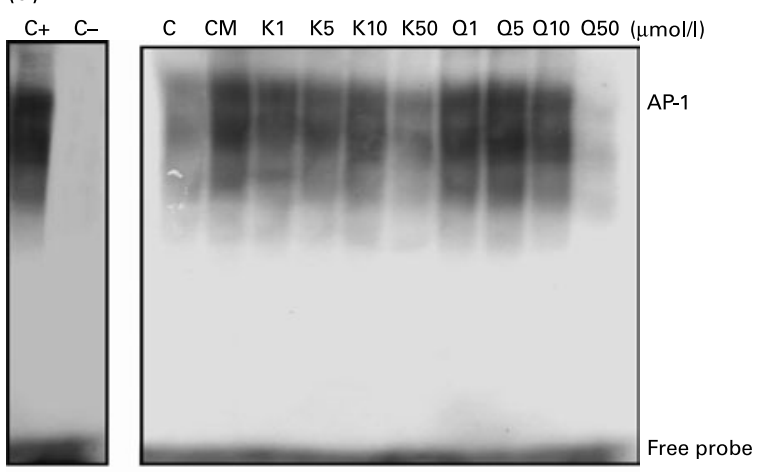

attenuated VCAM-1 expression also at $10 \mu \mathrm{mol} / \mathrm{l}$. Differences beween results from various studies could not simply be due to the source of endothelial cells because, except in the research by Lotito \& Frei $^{(49)}$ which cultured cells from human aorta, HUVEC were used in all other cases. A possible influence of experimental conditions such as cytokines or incubation times cannot be ruled out. Much less information exists on the expression of iNOS and COX-2 in endothelial cells. Both anti-inflammatory genes appear to be up-regulated in HUVEC $^{(50)}$, but there is no previous study reporting effects of flavonoids on iNOS expression in this cell type, and it has been even recently shown that isoflavones may stimulate HUVEC prostacyclin production through effects on COX-2 expression ${ }^{(51)}$. Results from the present study indicate that both iNOS and COX-2 protein levels are markedly increased in cytokine-stimulated HUVEC, and that the flavonols kaempferol and quercetin significantly attenuate this effect in a concentration-dependent manner.

Stronger inhibitory effects on adhesion molecule expression were induced by kaempferol, reaching even a full inhibition of E-selectin expression at $50 \mu \mathrm{mol} / \mathrm{l}$. Thus, our data demonstrate that the number of $-\mathrm{OH}$ moieties on the B-ring is not directly related to the potency of kaempferol and quercetin for inhibiting expression of VCAM, ICAM-1 and E-selectin in HUVEC. Nevertheless, a relationship with the antioxidant activity could be involved, because data from flow cytometry suggest a more efficient inhibition of ROS and RNS generation by kaempferol.
In fact, reduced effects on adhesion molecule gene expression of quercetin conjugates, whose antioxidant activity is about half that of the aglycone, have been very recently reported ${ }^{(23)}$. Given the fact that oxidative stress up-regulates VCAM- 1 and E-selectin expression via redox-sensitive activation of transcription factors ${ }^{(49)}$, differential effects of treatment with both flavonols might be explained by a local antioxidant effect on endothelial cells and subsequent modulation of cell signalling and gene expression. A pivotal factor in inflammatory diseases is NF- $\kappa \mathrm{B}$. It is widely recognised that induction of endothelial adhesion molecules by inflammatory cytokines strongly depends on activation of NF- $\kappa B^{(52)}$, and previous studies have demonstrated that flavones and flavonols inhibit nuclear translocation and DNA binding of NF- $\mathrm{BB}$ in $\mathrm{HUVEC}^{(15)}$. The ICAM-1 and VCAM-1 promoters also contains several AP-1 binding sites that may be important for expression of these adhesion molecules ${ }^{(53)}$. AP-1 is another redox-sensitive factor whose activation may be inhibited by flavonoids ${ }^{(54,55)}$. In the present study, although activation of both NF- $\mathrm{B}$ and AP-1 was attenuated by treatment with both kaempferol and quercetin, the inhibitory effect did significantly differ only at a concentration of $50 \mu \mathrm{mol} / 1$ and was higher in the case of quercetin. Thus, the effects of kaempferol and quercetin on the expression of the adhesion molecules and the activation of NF- $\mathrm{B}$ and AP-1 markedly differed. A similar situation has been recently described for the effect of different flavonoids in human aortic endothelial cells ${ }^{(49)}$. Therefore, data obtained suggest a more complex mechanism than inhibiton of redox-sensitive transcription factors for the effect of kaempferol and quercetin on the expression of adhesion molecules. Polyphenols may affect many biological activities not only through their antioxidant effect, but also by interacting with specific molecular targets in the cell machinery. Thus, it appears that a bioactivation of quercetin to quinine or quinine methionine metabolites occurs within HepG2 and Caco cells, resulting in covalent interactions between quercetin and cellular DNA and protein ${ }^{(56)}$, and it has been reported in HeLa cells that quercetin blocks Hsp72 translocation from the cytoplasm to the nucleus, probably at the level of the nuclear envelope ${ }^{(57)}$. Although no reports exist on kaempferol binding to receptor molecules, this flavonoid exhibit lower energy and smaller molecular volume size than quercetin ${ }^{(58)}$, two characteristics which modify steric and electronic interactions between the compounds and the biological receptors. Therefore, specific binding and interactions could explain, at least in part, the differential effects of quercetin and kaempferol. In addition, how adhesion molecules are selectively modulated in response to pro-inflammatory cytokines and which signalling pathways are involved in the selective regulation of these genes remains partially unknown. Quercetin has been reported to inhibit ICAM-1 expression induced by phorbol 12-myristate 13-acetate or TNF- $\alpha$ without NF- $\kappa \mathrm{B}$ activation in the human endothelial cell line ECV $304^{(59)}$. In addition, a flavonoid 2-(3-amino-phenyl)-8-methoxy-chromene-4-one selectively blocked TNF-induced VCAM-1 expression in human aortic endothelial cells by an NF- $\mathrm{KB}$-independent mechanism ${ }^{(60)}$. It has been proposed that, in addition to attenuating NF-кB or AP-1 activation, phenolic compounds may exert their anti-inflammatory activity by inhibiting ERK1/2 phosphorylation or JAK/STAT-1 activation $^{(41)}$.

Regulation of iNOS and COX-2 expression is also complex. Pathways of induction seem to converge in the activation of 
$\mathrm{NF}-\kappa \mathrm{B}^{(61)}$, but the relationship between flavonoids and the NF- $\kappa \mathrm{B}$ pathway is inconsistent. Thus, it has been reported that dietary quercetin does not reduce NF- $\kappa \mathrm{B}$ activation in the renal cortex of rats with established chronic glomerular disease $^{(62)}$, and that while both quercetin and kaempferol down-regulate iNOS expression in RAW264.7 cells, they do not suppress DNA binding activation of NF- $\mathrm{KB}^{(63)}$. Howewer, in Chang Liver cells, both flavonols inhibit iNOS and COX-2 expression and the activation of $\mathrm{NF}-\kappa \mathrm{B}^{(8)}$, and activation of both NF- $\mathrm{KB}$ and AP-1 is blocked in parallel to a down-regulation of COX-2 in bacterial lipopolysaccharide-activated macrophages $^{(64)}$. The present study identified how different concentrations of kaempferol and quercetin inhibit NF-кB and AP-1 in cytokine-stimulated HUVEC. However, the type of response in transcription factors and in the expression of iNOS and COX-2 differed, because effects on the activation of NF- $\mathrm{KB}$ and AP-1 tended to be higher at supraphysiological concentrations, mainly for quercetin, while there was a significant down-regulation of gene expression at concentrations of $5-10 \mu \mathrm{M}$, with a stronger response to quercetin. A combination of mechanisms may be again responsible for the differential effects of both flavonols and, in addition to those previously mentioned, other effects which require to be explored, such as changes in $\mathrm{C} / \mathrm{EBP} \delta$, interferon regulatory factor-1 or Akt signalling pathways ${ }^{(64-66)}$, could be involved.

Because flavonoids suffer intestinal degradation, absorption and metabolism, it is important to note that data from cell-culture studies cannot be directly extrapolated to in vivo. Nevertheless, given the potential use of flavonoids as nutritional supplements for prophylaxis or therapy of certain diseases, the conversion of glucuronide conjugates of flavonoids to free aglycones at sites of inflammation, and the development of novel delivery systems aimed to improve stability and bioavailabilty of these molecules ${ }^{(25,26)}$, testing of the anti-inflammatory effects of both physiological and supraphysiological doses of flavonoid aglycones is clearly required to deepen our understanding of the molecular mechanisms of action and the potential applications of these molecules. Results from the present study indicate that, although closely related in structure, the antioxidant and anti-inflammatory efficiencies of kaempferol and quercetin differ significantly, and that structural features required for regulation of the activation of NF- $\kappa \mathrm{B}$ or AP-1 are not enough to explain differences among both flavonols in down-regulation of anti-inflammatory gene expression in cytokine-stimulated HUVEC.

\section{Acknowledgements}

The present study was supported by the Plan Nacional de I+D, Spain (grant no. BFI2003-03114). All authors contributed equally for intellectual input and writing of the manuscript. All authors declare no conflict of interest.

CIBEREHD is funded by the Instituto de Salud Carlos III.

\section{References}

1. Cines DB, Pollak ES, Buck CA, et al. (1998) Endothelial cells in physiology and in the pathophysiology of vascular disorders. Blood 91, 3527-3561.
2. Price DT \& Loscalzo J (1999) Cellular adhesion molecules and atherogenesis. Am J Med 107, 85-97.

3. Iiyama K, Hajra L, Iiyama M, Li H, DiChiara M, Medoff BD \& Cybulsky MI (1999) Patterns of vascular cell adhesion molecule-1 and intercellular adhesion molecule- 1 expression in rabbit and mouse atherosclerotic lesions and at sites predisposed to lesion formation. Circ Res 85, 199-207.

4. Unger RE, Krump-Konvalinkova V, Peters K \& Kirkpatrick CJ (2002) In vitro expression of the endothelial phenotype: comparative study of primary isolated cells and cell lines, including the novel cell line HPMEC-ST1.6R. Microvasc Res 64, 384-397.

5. Nachtigal P, Kopecky M, Solichova D, Zdansky P \& Semecky $\mathrm{V}$ (2005) The changes in the endothelial expression of cell adhesion molecules and iNOS in the vessel wall after the short-term administration of simvastatin in rabbit model of atherosclerosis. J Pharm Pharmacol 57, 197-203.

6. Ignarro LJ (1989) Biological actions and properties of endothelium-derived nitric oxide formed and released from artery and vein. Circ Res 65, 1-21.

7. Hayashi T, Matsui-Hirai I, Fukatsu A, Sumi D, Kano-Hayashi H, Arockia Rani J \& Iguchi A (2006) Selective iNOS inhibitor, ONO1714 successfully retards the development of high-cholesterol diet induced atherosclerosis by novel mechanisms. Atherosclerosis 187, 316-324.

8. García-Mediavilla V, Crespo I, Collado PS, Esteller A, Sánchez-Campos S, Tunón MJ \& González-Gallego J (2007) The anti-inflammatory flavones quercetin and kaempferol cause inhibition of inducible nitric oxide synthase, cyclooxygenase- 2 and reactive C-protein, and down-regulation of the nuclear factor $\mathrm{\kappa B}$ pathway in Chang Liver cells. Eur J Pharmacol 557, 221-229.

9. Martinez-González J \& Badimon L (2007) Mechanisms underlying the cardiovascular effects of COX-inhibition: benefits and risks. Curr Pharm Des 13, 2215-2227.

10. Cuccurullo C, Mezzetti A \& Cipollone F (2007) COX-2 and the vasculature: angel or evil? Curr Hypertens Res 9, 73-80.

11. González-Gallego J, Sánchez-Campos S \& Tuñón MJ (2007) Anti-inflammatory properties of dietary flavonoids. Nutr Hosp 22, 287-293.

12. Arai Y, Watanabe S, Kimira M, Shimoi K, Mochizuki R \& Kinae N (2000) Dietary intakes of flavonols, flavones and isoflavones by Japanese women and the inverse correlation between quercetin intake and plasma LDL cholesterol concentration. J Nutr 130, 2243-2250.

13. Geleijnse JM, Launer LJ, Van der Kuip DA, Hofman A \& Witteman JCM (2002) Inverse association of tea and flavonoid intakes with incident myocardial infarction: the Rotterdam Study. Am J Clin Nutr 75, 880-886.

14. Yu YM, Wang ZH, Liu CH \& Chen CS (2007) Ellagic acid inhibits IL-1 $\beta$ induced cell adhesion molecule expression in human umbilical vein endothelial cells. Br J Nutr 97, 692-698.

15. Choi JS, Choi YJ, Park SH, Kang JS \& Kang YH (2004) Flavones mitigate tumor necrosis factor- $\alpha$-induced adhesion molecule upregulation in cultured human endothelial cells: role of nuclear factor-кB. J Nutr 134, 1013-1019.

16. Kim DH, Cho KH, Moon SK, Kim YS, Kim DH, Choi SJ \& Chung HY (2005) Cytoprotective mechanism of baicalin against endothelial cell damage by peroxynitrite. J Pharm Pharmacol 57, $1581-1590$.

17. Odontuya G, Hoult JRS \& Houghton PJ (2005) Structureactivity relationship for anti-inflammatory effect of luteolin and its derived glycosides. Phytother Res 19, 782-786.

18. Peng IW \& Kuo SM (2003) Flavonoid structure affects the inhibition of lipid peroxidation in Caco-2 intestinal cells at physiological concentrations. J Nutr 133, 2184-2187.

19. Burda S \& Oleszek W (2001) Antioxidant and antiradical activities of flavonoids. J Agric Food Chem 49, 2774-2779. 
20. Karakaya S \& El SN (1999) Quercetin, luteolin, apigenin and kaempferol contents of some foods. Food Chem 66, 289-292.

21. Crespo I, García-Mediavilla MV, Almar M, González P, Tuñón MJ, Sánchez-Campos S \& González-Gallego J (2007) Differential effects of dietary flavonoids on reactive oxygen and nitrogen species generation and antioxidant enzymes in Chang Liver cells. Food Chem Toxicol (epublication ahead of print version 23 December 2007).

22. Williamson $G$ (2002) The use of flavonoid aglycones in in vitro systems to test biological activities: based on bioavailability data, is this a valid approach? Phytochem Rev 1, 215-222.

23. Tribolo S, Lodi F, Connor C, Suri S, Wilson VG, Taylor MA, Needs PW, Kroon PA \& Hughes DA (2008) Comparative effects of quercetin and its predominant human metabolites on adhesion molecule expression in activated human vascular endothelial cells. Atherosclerosis 197, 50-56.

24. Shimoi K, Saka N, Kaji K, Nozawa R \& Kinae N (2000) Metabolic fate of luteolin and its functional activity at focal site. Biofactors 12, 181-186.

25. Shimoi K \& Nakayama T (2005) Glucuronidase deconjugation in inflammation. Methods Enzymol 400, 263-272.

26. Ratnam DV, Ankola DD, Bhardwaj V, Shana DK \& Kumar MNVR (2006) Role of antioxidants in prophylaxis and therapy: a pharmaceutical perspective. J Control Release 113, 189-207.

27. Lucas-Abellán C, Fortea I, Gabaldón JA \& Nuñez-Delicado E (2008) Encapsulation of quercetin and myricetin in cyclodextrins at acidic pH. J Agric Food Chem 56, 255-259.

28. Wu TH, Yen FL, Lin LT, Tsai TR, Lin CC \& Cham TM (2008) Preparation, physicochemical characterization, and antioxidant effects of quercetin nanoparticles. Int $J$ Pharm 346, 160-168.

29. Gimbrone MA Jr, Topper JN, Nagel T, Anderson KR \& GarciaCardeña G (2000) Endothelial dysfunction, hemodynamic forces, and atherogenesis. Ann N Y Acad Sci 902, 230-240.

30. Müller JM, Rupec RA \& Baeuerle PA (1997) Study of gene regulation by $\mathrm{NF}-\mathrm{\kappa B}$ and $\mathrm{AP}-1$ in response to reactive oxygen intermediates. Methods 11, 301-312.

31. Kunsch C \& Medford RM (1999) Oxidative stress as a regulator of gene expression in the vasculature. Circ Res 85, 753-766.

32. Adhikari N, Charles N, Lehmann U \& Hall JL (2006) Transcription factors and kinase-mediated signalling in atherosclerosis and vascular injury. Curr Atheroscler Rep 8, 252-260.

33. Bea F, Kreuzer J, Preusch M, Schaab S, Isermann B, Rosenfeld ME, Katus H \& Blessing E (2006) Melagatran reduces advanced atherosclerotic lesion size and may promote plaque stability in apolipoprotein E-deficient mice. Arterioscler Thromb Vasc Biol 26, 2787-2792.

34. García-Mediavilla MV, Sánchez-Campos S, González-Pérez P, Gómez-Gonzalo M, Majano PL, López-Cabrera M, Clemente G, García-Monzón C \& González-Gallego J (2005) Differential contribution of hepatitis C virus NS5A and core proteins to the induction of oxidative and nitrosative stress in human hepatocyte-derived cells. J Hepatol 43, 606-613.

35. Kim JD, Liu L, Guo W \& Meydani M (2006) Chemical structure of flavonols in relation to modulation of angiogenesis and immune-endothelial cell adhesion. J Nutr Biochem 17, 165-176.

36. Mosmann T (1983) Rapid colorimetric assay for cellular growth and survival: application to proliferation and cytotoxicity assays. J Immunol Methods 65, 55-63.

37. Tuñón MJ, Sánchez-Campos S, Gutiérrez B, Culebras JM \& González-Gallego J (2003) Effects of FK506 and rapamycin on generation of reactive oxygen species, nitric oxide production and nuclear factor $\mathrm{\kappa B}$ activation in rat hepatocytes. Biochem Pharmacol 66, 439-445.

38. Gutiérrez MB, Miguel BS, Villares C, Tuñón MJ \& GonzálezGallego J (2006) Oxidative stress induced by Cremophor EL is not accompanied by changes in NF- $\mathrm{kB}$ activation or iNOS expression. Toxicology 222, 125-131.

39. Dias AS, Porawski M, Alonso M, Collado PS, Marroni N \& González-Gallego J (2005) Quercetin decreases oxidative stress and NF- $\mathrm{KB}$ activation and iNOS overexpression in liver of streptozotocin-induced diabetic rats. J Nutr 135, 2299-2304.

40. Pannala AS, Rice-Evans CA, Halliwell B \& Singh S (1997) Inhibition of peroxynitrit-mediated tyrosine nitration by catechin polyphenols. Biochem Biophys Res Commun 232 164-168.

41. Wang L, Tu YC, Lian TW, Hung JT, Yen JH \& Wu MJ (2006) Distinctive antioxidant and anti-inflammatory effects of flavonols. J Agric Food Chem 54, 9798-9804.

42. Cao G, Sofic E \& Prior RL (1997) Antioxidant and prooxidant behaviour of flavonoids: structure-activity relationships. Free Radic Biol Med 22, 749-760.

43. Wang H \& Joseph JA (1999) Structure-activity relationships of quercetin in antagonizing hydrogen peroxide-induced calcium dysregulation in PC12 cells. Free Radic Biol Med 27, 683-694.

44. Areias FM, Rego AC, Oliveira CR \& Seabra RM (2001) Antioxidant effect of flavonoids after ascorbate/ $\mathrm{Fe}(2+)$-induced oxidative stress in cultured retinal cells. Biochem Pharmacol 62, 111-118.

45. Arora A, Nair MG \& Strasburg GM (1998) Structure-activity relationships for antioxidant activities of a series of flavonoids in a liposomal system. Free Radic Biol Med 24, 1355-1363.

46. Long LH, Clement MV \& Halliwell B (2000) Artifacts in cell culture: rapid generation of hydrogen peroxide on addition of (-)-epigallocatechin, (-)-epigallocatechin gallate, (+)-catechin, and quercetin to commonly used cell culture media. Biochem Biophys Res Commun 273, 50-53.

47. Yokomizo A \& Moriwaki M (2006) Effects of uptake of flavonoids on oxidative stress induced by hydrogen peroxide in human intestinal Caco-2 cells. Biosci Biotechnol Biochem 70 , $1317-1324$.

48. Gerritsen ME, Carley WW, Ranges GE, Shen CP, Phan SA, Ligon GF \& Perry CA (1995) Flavonoids inhibit cytokineinduced endothelial cell adhesion protein gene expression. $A m$ J Pathol 147, 278-292.

49. Lotito SB \& Frei B (2006) Dietary flavonoids attenuate tumor necrosis factor $\alpha$-induced adhesion molecule expression in human aortic endothelial cells. Structure-function relationships and activity after first pass metabolism. J Biol Chem 281, 37102-37110.

50. Minici F, Miceli F, Tiberi F, Tropea A, Orlando M, Gangale MF, Romani F, Catino S, Lanzone A \& Apa R (2007) Ghrelin in vitro modulates vasoactive factors in human umbilical vein endothelial cells. Fertil Steril 88, 1158-1166.

51. Hermenegildo C, Oviedo PJ, García-Pérez MA, Tarín JJ \& Cano A (2005) Effects of phytoestrogens genistein and daidzein on prostacyclin production by human endothelial cells. $J$ Pharmacol Exp Ther 315, 722-728.

52. Collins T, Read MA, Neish AS, Whitley MZ, Thanos D \& Maniatis $T$ (1995) Transcriptional regulation of endothelial cell adhesion molecules: NF- $\mathrm{\kappa B}$ and cytokine-inducible enhancers. FASEB J 9, 899-909.

53. Simoncini T, Maffei S, Basta G, Barsacchi G, Genazzani AR, Liao JK \& De Caterina R (2000) Estrogens and glucocorticoids inhibit endothelial vascular cell adhesion molecule-1 expression by different transcriptional mechanisms. Circ Res 87, 19-25.

54. Chen CC, Chow MP, Huang WC, Lin YC \& Chang YJ (2004) Flavonoids inhibit tumour necrosis factor- $\alpha$-induced up-regulation of intercellular adhesion molecule-1 (ICAM-1) in respiratory epithelial cells through activator protein-1 and nuclear factor-кB: structure-activity relationships. Mol Pharmacol 66, $683-693$ 
55. Park JS, Kim MH, Chang HJ, Kim KM, Kim SM, Shin BA, Ahn BW \& Jung YD (2006) Epigallocatechin-3-gallate inhibits the PDGF-induced VEGF expression in human vascular smooth muscle cells via blocking PDGF receptor and Erk-1/2. Int $J$ Oncol 29, 1247-1252.

56. Walle T, Vincent TS \& Walle UK (2003) Evidence of covalent binding of dietary flavonoid quercetin to DNA and protein in human intestinal and hepatic cells. Biochem Pharmacol 65, $1603-1610$.

57. Jakubowicz-Gil J, Pawlikowska-Pawlega B, Piersiak T, Pawelec J \& Gawron A (2005) Quercetin suppresses heat shock-induced nuclear translocation of Hsp72. Folia Hystochem Citobiol 43, $123-128$

58. Xu YC, Leung SWS, Yeung DKY, Hu LH, Chen GH, Che CM \& Man RYK (2007) Structure-activity relationships of flavonoids for vascular relaxation in porcine coronary artery. Phytochemistry 68, 1179-1188.

59. Kobuchi H, Roy S, Sen CK, Nguyen MHG \& Packer L (1999) Quercetin inhibits inducible ICAM-1 expression in human endothelial cells through the JNK pathway. Am J Physiol 277, C403-C411.

60. Wolle J, Hill RR, Ferguson E, Devall LJ, Trivedi BK, Newton RS \& Saxena U (1996) Selective inhibition of tumor necrosis factor-induced vascular cell adhesion molecule-1 gene expression by a novel flavonoid. Lack of effect on transcription factor NF-кB. Arterioscler Thromb Vasc Biol 16, 1501-1508.
61. Jiang B, Xu S, Hou X, Pimentel DR, Brecher P \& Cohen RA (2004) Temporal control of NF- $\mathrm{B}$ activation by ERK differentially regulates interleukin- $1 \beta$-induced gene expression. J Biol Chem 279, 1323-1329.

62. Rangan GK, Wang Y \& Harris DC (2002) Dietary quercetin augments activator protein-1 and does not reduce nuclear factor- $\mathrm{\kappa} \mathrm{B}$ in the renal cortex of rats with established chronic glomerular disease. Nephron 90, 313-319.

63. Kim BH, Cho SM, Reddy AM, Kim YS, Min KR \& Kim Y (2005) Down-regulatory effect of quercitrin gallate on nuclear factor- $\mathrm{kB}$-dependent inducible nitric oxide synthase expression in lipopolysaccharide-stimulated macrophages RAW 264.7. Biochem Pharmacol 69, 1577-1583.

64. Hou DX, Yanagita T, Uto T, Masuzaki S \& Fujii M (2005) Anthocyanidins inhibit cyclooxygenase-2 expression in LPSevoked macrophages: structure-activity relationship and molecular mechanisms involved. Biochem Pharmacol 70, 417-425.

65. De Stefano D, Miauri MC, Iovine B, Ialenti A, Bevilacqua MA \& Carnuccio R (2006) The role of NF-kB, IRF-1, and STAT-1 $\alpha$ transcription factors in the iNOS gene induction by gliadin and IFN- $\gamma$ in RAW 264.7 macrophages. J Mol Med 84, 65-74.

66. Kang JS, Yoon YD, Han MH, Han SB, Lee K, Park SK \& Kim HM (2007) Equol inhibits nitric oxide production and inducible nitric oxide synthase gene expression through down-regulating the activation of Akt. Int Immunopharmacol 7, 491-499. 